Journal of Life Economics

Cilt / Volume 6, Say1 / Issue 3, 2019, pp. 361-378

E - ISSN: 2148-4139

URL: http://www.ratingacademy.com.tr/ojs/index.php/jlecon

DOİ: https://doi.org/10.15637/jlecon.6.022

Araştırma Makalesi/Research Article

\title{
KAMU ÖZEL SEKTÖR ORTAKLIĞI VE KREDİ YURTLAR KURUMU UYGULAMASI: ÇANAKKALE İLİ ÖRNEĞİ
}

\author{
THE PUBLIC PRIVATE PARTNERSHIP WITH CREDIT AND HOSTELS \\ INSTITUTION PRACTICE: THE CASE OF CANAKKALE PROVINCE \\ Mehmet Emin KENANOĞLU *
}

\author{
* Arş. Gör., Çanakkale Onsekiz Mart Üniversitesi, Biga İktisadi ve İdari Bilimler Fakültesi, Maliye \\ Bölümü,TÜRKIYE, E-mail: mehmeteminkenanoglu@comu.edu.tr \\ ORCID ID: https://orcid.org/0000-0003-1044-6674
}

Geliş Tarihi: 4 Temmuz 2019; Kabul Tarihi: 25 Temmuz 2019

Received: 4 July 2019; Accepted: 25 July 2019

\begin{abstract}
$\ddot{O Z Z E T}$
Kamu Özel Sektör Ortaklĭ̆ modeli kamu yatırımlarından kaynaklanan maliyetlerin azaltılması, özel sektörün konforunun kamu hizmetinde yaşatılması, riskin etkin dağıtılması, devletin sunacă̆ mal ve hizmetlerin yapım işlerinin bütçe yetersizliği nedeniyle ertelenmesinin veya yapılamamasının önüne geçmesi gibi birçok fayda doğurmaktadır. Bu çalışmada Kamu Özel Sektör Ortaklı̆̆l modeli ile kiralanan Kredi Yurtlar Kurumu yurtlarındaki durum incelenmiştir. Araştırmada nitel araştırma yöntemi olarak derinlemesine görüşme tekniği kullanılmıştır. Araştırmanın katılımcılarını, Çanakkale ilindeki Kredi Yurtlar Kurumu yurtlarının yöneticileri oluşturmaktadır. Yöneticiler ile yapılan görüşmeler neticesinde Kamu Özel Sektör Ortaklı̆̆ı modeli ile kiralanan yurtların özellikleri, nitelikleri, ortaya çıkardığ l etkileri, olumlu ve olumsuz yanları gibi durumların ortaya konması amaçlanmıştır. Literatürde yurt yapımında Kamu Özel Sektör Ortaklığı modelinin kullanılmasını konu alan spesifik bir çalışmanın olmaması ise çalışmanın önemini arttırmaktadır.
\end{abstract}

Anahtar Kelimeler: Kamu Özel Sektör Ortaklığı, Kredi Yurtlar Kurumu, Çanakkale

JEL Kodlarl: H2O, H52.

\section{ABSTRACT}

The Public Private Partnership model has many benefits such as reduction cost arising from public investments, ensure to comfort of the private sector in the public service, effective distribution risk, and to prevent postponement or inability of construction works of state goods and services due to insufficient budget. In this study, the situation in the Credit and Hostels Institution which is rented with Public Private Partnership model is examined and in this research interview technique as a qualitative research method was used. The participants of the study are the managers of the Credit and Hostels Institution in Canakkale province. As a result of the interviews conducted with the managers, it was aimed to reveal characteristics, qualities, effects, positive and negative aspects of the rented dormitories with the Public Private Partnership model in the literature the lack of a specific study on the use of Public Private Partnership model in the construction of dormitories. Hence increases the importance of the study.

Key Words: Public Private Partnership, Credit and Hostels Institution, Canakkale.

JEL Codes: H2O, H52. 


\section{GİRIŞ}

Kamu Özel Sektör Ortaklığı (KÖSO), bütçe yetersizliği nedeniyle devletin sunmak istediği mal ve hizmetlerin aksamasını önlemeyi amaç edinen görece olarak yeni bir konsept olarak ifade edilmektedir. Bu finansman modelinin uygulamada hem avantaj hem de dezavantajları bulunmaktadır. Örneğin, hükümetlere yeni mali alan yaratarak avantajlar sağlarken, doğurduğu mali riskler, şeffaflık ile sürdürülebilirlik noktasındaki endişeler ve bu modele ait tekil bir mevzuatın olmaması gibi birçok nokta, modelin dezavantajlarından bazılarını oluşturmaktadır. Bu çalışmada, KÖSO modeline ilişkin kavramsal çerçeve ve konu ile ilgili çalışmalar incelenmiştir. Temel amacı yatırım finansmanı olan bu modelin genellikle eğitim, sağlık, altyapı ve enerji gibi birçok sektörde kullanıldığı görülmektedir. Ancak 2008 y1lında 351 sayılı Kredi ve Yurtlar Kurumu Kanununun 20. maddesine eklenen bir fikra ile yurt yapımının da önü açılmıştır. Bu noktadan hareketle çalışmada öncelikle geniş bir literatür taraması yapılmış, ayrıca derinlemesine görüşme yöntemi kullanılarak Çanakkale'deki 3 Kredi Yurtlar Kurumu (KYK) yurt yöneticisi ve Çanakkale İl Müdürlüğüne bağlı İdari İşler ve İnşaat Emlak Şube Müdürü ile görüşme gerçekleştirilmiştir. Yapılan görüşmelerde KÖSO modeli ile kiralanan yurtların özellikleri, nitelikleri, ortaya çıkardı̆̆ı etkiler, olumlu- olumsuz yanları ve bu model ile faaliyete geçen yurtların sürdürülebilirlikleri gibi konularda görüşülen kişilerin deneyimlerden faydalanılmıştır. Gerçekleştirilen görüşmeler kapsamında hedeflenen; görüşülen kişilerin Çanakkale'deki KÖSO modeli ile kiralanan KYK yurt ve hizmetleri ile ilgili kanaatlerini ve bakış açılarını ortaya koymak olmuştur. KYK yurtlarının KÖSO modeli ile finansmanı konusunun literatürde sınırlı olması ve genellikle diğer sektörlere yönelik çalışmaların yaygın olması konunun önemini arttırmaktadır.

\section{KAMU ÖZEL SEKTÖR ORTAKLIĞI MODELINE ILIŞKİN KAVRAMSAL ÇERÇEVE}

İktisadi ve sosyal hayattaki ilerlemenin sağlanmasında önemli bir role sahip olan hükümetler ve kamu idareleri sahip oldukları eski geleneksel çalışma alışkanlıkları ile idari yapılarından kaynaklı olarak her zaman kendilerinden beklenen yeni görevleri yerine getirememişlerdir (Kesik ve Telli, 2014: 80). Yeni görevlerde yaşanan bu sorunların çözüm noktasında ise KÖSO ya da uluslararası alanda bilinen adıyla Public Private Partnership, yeni bir finansman modeli olarak ortaya çıkmıştır. Bu finansman modeli, yüksek sermaye isteyen enerji, sağlık, eğitim, ulaşım ve altyapı yatırımları gibi büyük projelerin yürütülebilmesine olanak sağlamıştır (Uygun, 2013: 25; CDC, 2018: 2).

KÖSO kavramına ilişkin uluslararası literatürde birçok tanım bulunmaktadır. Tanımlama konusunda yaşanan bu durum, modelin kolaylıkla açıklanıp, anlaşılması noktasında bazı zorlukların doğmasına neden olmaktadır. Neredeyse her uluslararası kuruluş, modelin farklı bir özelliğine atıf yaparak, yeni bir tanımlama yoluna gitmiştir. Bu bağlamda, sıklıkla yararlanılan Dünya Bankası tanımına göre; KÖSO modeli, “Özel sektörün, risk ve yönetim sorumluluğu aldĭ̆l, kamu mal ve hizmetlerinin să̆lanması amacıyla, tarafların uzun dönemli yükümlülükleri üstlendikleri sözleşmeleri" ifade etmektedir. Ekonomik İşbirliği ve Kalkınma Örgütü yani OECD, bu modeli, "Devletle bir veya daha fazla özel sektör oyuncusunun bir araya gelerek, tarafların farklı beklentileri çerçevesinde karşılıklı uzlaşma sağlanması sonucu ortaya çıkan anlaşma" olarak tanımlamaktadır (Kalkınma Bakanlığı, 2018: 6). Kanada Konseyi KÖSO kavramını, "Açıkça tanımlanmış kamu ihtiyaçlarını; kaynakların, risklerin ve karşılıkların uygun şekilde tahsisi yoluyla en iyi şekilde karşılamayı amaç edinen ve her bir

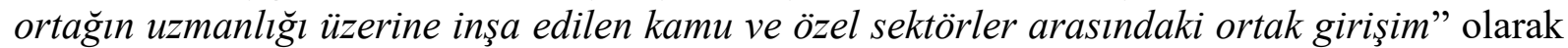
ifade etmektedir (ACEC, 2010: 6). Uluslararası Gıda Politikası Araştırma Enstitüsü ise; "Kamu kurumlarl ve özel kuruluşların, ürün ve hizmetlerin üretimi ve sunulmasında daha fazla verimlilik elde etmek için kaynak, bilgi ve riskleri paylaştı̆̆ mekanizmalar" olarak ifade etmektedir (Hartwich, 2007: vii). Yapılan tanımlamalardan hareketle, KÖSO modelini; 
kamusal mal ve hizmetlerin sağlanması amacıyla tarafların farklı beklentileri çerçevesinde inşa edilen, kaynak ve risklerin bir sözleşmeye dayandırılarak tahsis edildiği bir yapı olarak tanımlamak mümkündür.

Devlet ile özel sektör arasındaki işbirliğinin gelişimi, 16. yüzyılda devletin etkin rolünü belirlemeye çalışan iktisatçılar tarafindan başlatılmıştır (Mostepaniuk, 2016: 385). Dünyadaki ilk KÖSO uygulamaları 17. ve 18. yüzyıllarda, ağırlıklı olarak kanal ve köprü yapımında, imtiyaz sistemiyle gerçekleştirilmiş olup bazı altyapı hizmetleri Avrupa'da 19. yüzyılda özel sektör tarafından kurularak işletilmiş; özellikle II. Dünya Savaşı sonrası Fransa, İtalya, Japonya ve Amerika Birleşik Devletleri gibi bazı ülkelerde karayolu ağlarının inşası ile yaygınlaşmıştır (Çinar vd., 2011: 219).

KÖSO modelinin ilk uygulandığı ülkelerden biri de Türkiye olmuştur. Türkiye'de uzun yıllardır özellikle Yap-İşlet-Devret modeli ile gerçekleştirilen projelerin hemen tamamı aslında bir KÖSO uygulaması mahiyetindedir. Özellikle enerji sektöründe, yenilenebilir enerji yatırımları, 3. köprü (Yavuz Sultan Selim Köprüsü) ve 3. havalimanı (İstanbul Havalimanı) ile Gebze- Orhangazi- İzmir Otoyolu kamuoyunun oldukça aşina olduğu yatırımlardan bazılarıdır (DINAMO, 2018: 2). Türkiye'de KÖSO projelerinin yaygın kullanımı 1994 yılında çıkarılan 3996 sayılı "Bazı Yatırım ve Hizmetlerin Yap-Isslet-Devret Modeli ile Yaptırılması Hakkında Kanun" kapsamında gerçekleştirilen yatırımlara dayanmaktadır. KÖSO projeleri 3359 sayılı "Sağlık Hizmetleri Temel Kanunu" ile yeni bir boyut kazanmıştır. Bu noktada Yap-Kirala modeli çerçevesinde bir dizi entegre sağlık kampüsünün hayata geçirilmesi öngörülmüştür. Ayrıca 652 sayılı "Milli Eğitim Bakanlı̆̆ının Teşkilat ve Görevleri Hakkında Kararname" ile eğitim- öğretim tesislerinin ve 351 sayılı "Yüksek Öğretim Kredi ve Yurtlar Kurumu Kanunu" ile de yurt yapımının önü açılmıştır (Kesik ve Telli, 2014: 84).

KÖSO ile özellikle devletin sunacağı mal ve hizmetlerin, yapım işlerinin bütçe yetersizliği nedeniyle ertelenmesinin veya yapılamamasının önüne geçmek amaçlanmaktadır. Temel nedeni yatırım finansmanı olmak üzere, kamu yatırımlarından kaynaklanan maliyetlerin azaltılması, özel sektörün sağladığı konforun kamu hizmetinde yaşatılması, riskin etkin dağıtılması gibi faydalar tercih nedeni olmasını sağlamaktadır. Özel sektör açısından ise sahip olunan çeşitli imtiyazlarla yatırımın geri dönüşümü teminat altına alınmaktadır (Uygun, 2013: 25). KÖSO'dan beklenen yararların ortaya çıkması, ortakların en düşük maliyetle en fazla yarar sağlayabilmeleri için KÖSO felsefesinin iyi anlaşılması gerekmektedir. Bu temelde sağlam bir çerçeve ortaya konulmalıdır. KÖSO, gerekli koşullar oluşturulup uygulama alanı ve etkinliği arttırıldıkça kamu maliyesi üzerinde de önemli etkilere neden olduğu görülmektedir. Bu etkilerinse olumlu ya da olumsuz olması mümkündür. Bu olas1 etkilerden hangisinin daha baskın olacağı ise zamana ve yapılan işe göre değişim göstermektedir (Şahin ve Uysal, 2012: 157). KÖSO’nun sahip olduğu faydaları ifade etmek gerekirse (Çerçi, 2011: 19-20);

- İlave sermaye/kaynak temin etmek,

- Alternatif yönetim ve uygulama becerileri sağlamak,

- Geniş anlamda kamuya/tüketiciye daha yüksek bir katma değer yaratmak,

- İhtiyaçların daha doğru belirlenmesini ve kaynakların optimal kullanımını sağlamak,

- Altyapı yatırımlarının hızlandırılması,

- Hizlı uygulama imkânı,

- Düşük toplam proje maliyeti,

- Daha iyi risk dağılımı,

- Performans için daha iyi teşvikler,

- Daha iyi hizmet kalitesi,

- İlave gelir yaratılması ve,

- Kamu yönetiminin iyileştirilmesidir. 
KÖSO'ların başarılı olması için öncelikle işin arka planını araştırmak, potansiyel iş ortağının ilgi alanlarını öğrenmek, ortaklığa yönelik imaj ve motivasyon çalışmaları, sosyal ve çevresel sorumluluğu önemsemek ve mali yapı oldukça önemli görünmektedir (CDC, 2018: 4). Ayrıca ortaklardan her biri projeye bir şekilde değer katmalı, ortaklar hem risk, hem de getirileri paylaşmalı ve ortaklık uzun süreli ve ilişkisel olmalıdır (Şahin ve Uysal, 2012: 158). KÖSO kurulduktan sonra ise iyi bir yönetimin sahip olması gereken bazı özellikler bulunmaktadır. Birleşmiş Milletler Avrupa Ekonomik Komisyonu, UNECE, iyi bir yönetime sahip olabilmesini ise 6 temel prensibe bağlamıştır. Bunlar (IBRD, 2014: 66-67);

- Verimlilik: Kaynak kullanımında israf, gecikme ve yolsuzlukların önlenmesi ile gelecek nesiller üzerine gereksiz yük yüklenmemesi,

- Sorumluluk: Politik aktörlerin eylemleri için topluma karş1 ne ölçüde sorumlu olduklarının bilinmesi,

- Şeffaflı: Kararların şeffaf ve açık olması,

- Kararlar: İnsanlara zarar vermeden kuralların geliştirilmesi ve uygulanmas1,

- Adalet: Toplumun bütün bireylerine kurallar çerçevesinde eşit davranılması ve,

- Katılım: Tüm paydaşların sürece katılımı olarak ifade edilmektedir.

Dünya Bankası verilerine göre, 1990-2016 yılları arasında gelişmekte olan ülkelerde KÖSO yöntemiyle toplam 2,6 trilyon Amerikan doları (USD) tutarında 7.132 adet proje gerçekleştirilmiştir. Yine Dünya Bankası, 1990-2015 yılları arasında gelişmekte olan ülkelerde en fazla proje stokuna sahip ilk 10 ülkeyi şöyle sıralamaktadır (TASAV, 2017: 1-2);

- Brezilya - 517 milyar USD

- Hindistan - 343 milyar USD

- Türkiye - 165 milyar USD

- Rusya - 155 milyar USD

- Çin - 145 milyar USD

- Meksika - 142 milyar USD

- Arjantin - 98 milyar USD

- Filipinler - 73 milyar USD

- Endonezya - 72 milyar USD

- Şili $\quad-69$ milyar USD

Dünya Bankası verilerinde görüldüğü üzere KÖSO uygulamaları Türkiye'de oldukça önemli boyuta ulaşmıştır. Türkiye'de uygulanmakta olan; Yap-İşlet-Devret, Yap-İşlet, YapKirala-Devret ve İşletme Hakkı Devri gibi modelleri de içine almakla birlikte, Tasarla-Yapİşlet, Yap-Sahiplen-İşlet, İlave Yatırım Yap-İşlet-Devret ve Özel Sektörle Şirket Kurma gibi henüz uygulanmayan farklı işbirliği modellerini de kapsamaktadır (Çerçi, 2011: 13-14). Türkiye'de 1986 yılından itibaren gerçekleştirilen KÖSO yatırımlarının bedelleri ve sektörel dağılımları Tablo 1'deki gibidir. 
Tablo 1: KÖSO Sektörel Dağılımları ve Proje Bedelleri (USD) (1986-2018)

\begin{tabular}{|l|c|r|c|}
\hline \multicolumn{1}{|c|}{ Sektör } & Proje Sayısı & Sözleşme Bedeli & Sözleşme Oranı (\%) \\
\hline Karayolu & 42 & 20.151 .695 .474 & 14,41 \\
\hline Havaalanı & 19 & 71.502 .473 .394 & 51,15 \\
\hline Yat Limanı ve Turizm Tesisi & 17 & 1.797 .258 .621 & 1,28 \\
\hline Demiryolu & 1 & 272.385 .860 & 0,19 \\
\hline Kültür ve Turizm Tesisi & 1 & 140.882 .493 & 0,10 \\
\hline Gümrük Tesisi & 16 & 469.140 .067 & 0,33 \\
\hline Endüstriyel Tesis & 2 & 1.432 .806 .660 & 1,02 \\
\hline Sağlık Tesisi & 21 & 12.057 .046 .669 & 8,62 \\
\hline Enerji & 89 & 28.837 .517 .331 & 20,52 \\
\hline Liman & 22 & 2.736 .143 .726 & 2,63 \\
\hline Madencilik & 8 & 366.665 .763 & 0,26 \\
\hline Toplam & $\mathbf{2 3 8}$ & $\mathbf{1 3 9 . 7 6 4 . 0 1 7 . 0 5 8}$ & $\mathbf{1 0 0 , 0 0}$ \\
\hline
\end{tabular}

Kaynak: (Cumhurbaşkanlığı Strateji ve Bütçe Başkanlığı, 2018).

Tablo 1'den de anlaşılacağı üzere, 1986 yılından 2018'e kadar olan süreçte toplamda 238 KÖSO projesi hayata geçirildiği ve bu projelerin toplamda yaklaşık 140 milyar USD'ye mal olduğu görülmektedir. Bu ortak yatırımlarının en önemli kısmı ise \%51.15'lik pay ile havaalanı yatırımlardan oluşmaktadır. KÖSO, çoğunlukla altyapı projelerini yürütmeyi ya da kamuya hizmet sağlamayı amaçlamaktadır. Bu tür taahhütler özel operatörleri ve kamu makamlarını kapsayan karmaşık yasal ve finansal düzenlemeleri içermektedir. Söz konusu düzenlemeler Avrupa Komisyonu'nun da ifade ettiği üzere çeşitli sektörlerde; ulaşım, enerji, altyapı, kamu güvenliği, atık yönetimi ve su dağıtımı alanlarında olmuştur (Talus, 2008: 347).

\section{LITERATÜR TARAMASI}

KÖSO modeli ile ilgili literatür taraması yapılırken, bu model ile ilgili birçok çalışmanın varlığı dikkat çekmiştir. Yapılan çalışmalar incelendiğinde, Kırgızistan, Hollanda, Birleşik Krallık ve Nijerya gibi birçok ülkede KÖSO uygulamalarına dair çalışmaların yapıldığı görülmüştür. Türkiye'de ise bu modele ilişkin çalışmaların daha çok sağlık sektörüne yönelik olduğu göze çarpmaktadır. Bu kapsamda, sağlık kampüslerinin mevzuat boyutu, şehir hastanelerinin hizmet kalitesinin memnuniyetinin ölçümü gibi çalışmalar söz konusudur. KÖSO modelinin ortaya çıkardığ 1 olumsuz yanları inceleyen çalışmalarda ise şeffaflık ve kazanç yönündeki kaygılar, sürdürülebilirlik konusundaki endişeler, tek bir mevzuatın olmaması ve modelin genel olarak başarısız olduğu konuları tartışılmıştır. Ayrıca çalışmalarda, Avrasya Tüneli, Osmangazi ve Yavuz Sultan Selim Köprülerinin doğurduğu geçiş garantisi ve döviz riskinin varlığı gibi hazinenin sahip olduğu mali risklerin varlığına da işaret edilmiştir. Söz konusu sorunlara yönelik çözüm önerilerinin geliştirilmesi adına model önerileri, modelin başarılı olmasına yardımcı olacak öneriler ve sürdürülebilirlik noktasındaki durumunun tartışılmasını konu alan çalışmalar da mevcuttur. Literatür taraması kapsamında yurt yapımında KÖSO modelinin uygulanmasına ilişkin bir çalışmaya rastlanılmamış ve yurt konusuna sadece birkaç çalışmada genel olarak çok kısa değinildiği görülmüştür. KÖSO konusunda yapılan literatür taramasını vermek gerekirse Tablo 2'deki gibidir. 
Tablo 2: KÖSO Konusunda Yapılan Çalışmalara Dair Literatür Taraması

\begin{tabular}{|c|c|}
\hline Araștırmacı(lar) & Çalış̧manın Kapsamı \\
\hline $\begin{array}{l}\text { Alexandersson ve } \\
\text { Hultén (2007) }\end{array}$ & $\begin{array}{l}\text { KÖSO'da risk dağılımının önemli olduğu ifade edilerek kilitlenme ve gecikme } \\
\text { sorunlarının yaşanmaması için sözleşme yapıları tartışılmıștır. }\end{array}$ \\
\hline Moszoro (2010) & $\begin{array}{l}\text { KÖSO'daki sermaye yapısının etkinliğini değerlendirilmesi için sunulan modelde farklı } \\
\text { yönetimsel becerilerin, bilgi aktarım şemalarının ve en uygun ortaklık yapısının nasıl } \\
\text { belirlendiğini göstermektedir. }\end{array}$ \\
\hline Verma (2010) & $\begin{array}{l}\text { KÖSO sözleşmelerindeki rekabet ve şeffaflık yönlerine odaklanmaktadır. Bunun içinde } \\
\text { Hindistan'daki hukuk uygulamaları ile uluslararası yasal çerçeveyi karşılaştırmakta ve } \\
\text { devletin uygulayabileceği yasal yaptırımlarla ilgili önerilerde bulunmaktadır. }\end{array}$ \\
\hline $\begin{array}{l}\text { Yereli ve Kizıltan } \\
\text { (2011) }\end{array}$ & $\begin{array}{l}\text { Kırgızistan için birçok alana yayılan yatırımların yapılabilmesi için bir çözüm önerisi } \\
\text { olarak KÖSO modelini önermiştir. }\end{array}$ \\
\hline Yetgin (2011) & $\begin{array}{l}\text { Kıyı yatıımlarında KÖSO modelinin uygulanabilirliğini, sektörün karşslaștı̆ı̆ riskleri, } \\
\text { modelinin başarılı sonuçlara ulaşabilmesi için sunulan önerileri tartışmışı. }\end{array}$ \\
\hline $\begin{array}{c}\text { Acartürk ve } \\
\text { Keskin (2012) }\end{array}$ & $\begin{array}{l}\text { Türkiye'de sağlık sektöründe KÖSO modelinin uygulanabilirliğini tartışarak, sağlık } \\
\text { hizmetlerinin etkin kullanımının sağlanması açısından önerilerde bulunmuștur. }\end{array}$ \\
\hline $\begin{array}{l}\text { Karahanoğulları } \\
(2012)\end{array}$ & $\begin{array}{l}\text { KÖSO modelinin geleneksel kamu hizmet üretme modeline göre mutlak bir } \\
\text { üstünlüğ̈ünün olmadı̆ğnı ve bu modelin sahip olduğu başarısızlıkları tartışmıștır. }\end{array}$ \\
\hline $\begin{array}{l}\text { Şahin ve Uysal } \\
\text { (2012) }\end{array}$ & $\begin{array}{l}\text { KÖSO mantı̆̆ ve kamusal hizmetlerin piyasalaşma sürecindeki yerini tartşarak, kamu } \\
\text { maliyesi üzerine olası etkilerini analiz etmiş ve kamu maliyesinin sürdürülebilirliği } \\
\text { noktasında önerilerde bulunmuştur. }\end{array}$ \\
\hline $\begin{array}{l}\text { Kahyaoğulları } \\
\quad(2013)\end{array}$ & $\begin{array}{l}\text { KÖSO politikalarının kabul edilme ve uygulanma süreçlerini gelişmiş ve gelişmekte olan } \\
\text { ülkeler açısından ele almıştır. Araştırmacı, gelişmekte olan ülke olarak Türkiye, gelişmiş } \\
\text { ülkeye örnek olarak Birleşik Krallık uygulamalarını incelemiștir. }\end{array}$ \\
\hline $\begin{array}{l}\text { Kesik ve Telli } \\
\text { (2014) }\end{array}$ & $\begin{array}{l}\text { KÖSO uygulamalarına değinilerek bu modele ilişkin dünya uygulamaları incelenmiş ve } \\
\text { Türkiye için bazı önerilerde bulunulmuştur. }\end{array}$ \\
\hline Şahin (2014) & $\begin{array}{l}\text { Gelissmekte olan ülkelerin mali alan yaratma noktasında önemli bir firsat olarak gördüğü } \\
\text { KÖSO'yu ve ortaya çıkardığı riskleri tartışmıştır. }\end{array}$ \\
\hline $\begin{array}{l}\text { Chisa ve di } \breve{g} \text {. } \\
\quad(2015)\end{array}$ & $\begin{array}{l}\text { Nijerya için altyapı yatırımlarının ekonomik büyüme üzerindeki etkisine değinerek } \\
\text { yetersiz sermaye birikimi ve az gelişmiş inşaat sektörünün bir kurtarıcısı olarak KÖSO’yu } \\
\text { ele almışlardır. }\end{array}$ \\
\hline $\begin{array}{l}\text { Tunç ve Özsaraç } \\
\qquad(2015)\end{array}$ & $\begin{array}{l}\text { Türkiye'deki KÖSO modelinin iyileştirilmesine yönelik önerileri; yasal çerçevenin } \\
\text { oturtulması, rekabetçi ve şeffaf ihale prosedürlerinin oluşturulması ve merkezi bir kamu } \\
\text { kurumuna öncelik verilmesi olarak ifade etmişlerdir. }\end{array}$ \\
\hline $\begin{array}{l}\text { Sundaram ve diğ. } \\
\text { (2016) }\end{array}$ & $\begin{array}{l}\text { Daha etkin çalışan bir KÖSO için yapılması gereken kurumsal yenilikler ve öneriler } \\
\text { tartışılmıştır. }\end{array}$ \\
\hline $\begin{array}{l}\text { Alagöz ve Yokuş } \\
\quad(2017)\end{array}$ & $\begin{array}{l}\text { KÖSO yatırımlarının sürdürülebilirliğini ile Türkiye'nin dış ekonomik dengesini } \\
\text { bozabileceği konuları tartışılmışır. Yapılan KÖSO yatırımlarının kısa vadede toplam } \\
\text { talebi arttırıcı etkisinin mali bir illüzyon yarattı̆̆ını ifade eden araştırmacılar, KÖSO'ların } \\
\text { ortaya çkaracağı muhtemel olumsuzlukların giderilmesi için birtakım çözüm önerileri } \\
\text { sunmaktadır. }\end{array}$ \\
\hline $\begin{array}{l}\text { Berksoy ve } \\
\text { Yildırım (2017), }\end{array}$ & $\begin{array}{l}\text { KÖSO ile bağlantılı kurumlarda çalışan } 178 \text { katılımcı ile anket çalışması yürütülmüsştür. } \\
\text { Elde edilen bulgular ile KÖSO modelinin sahip olduğu dezavantajlar ve bu eksiklikleri } \\
\text { gidermek adına birtakım önerilerde bulunulmuştur. }\end{array}$ \\
\hline $\begin{array}{l}\text { Çınar ve di ğ. } \\
\text { (2017) }\end{array}$ & $\begin{array}{l}\text { KÖSO modeliyle Türkiye'de açılan şehir hastanelerindeki hizmet memnuniyeti, } 250 \\
\text { katılımcı ile gerçekleștirilen anket çalışması aracilığıla ölçülmüștür. }\end{array}$ \\
\hline $\begin{array}{l}\text { Nederhand ve } \\
\text { Klijn (2017) }\end{array}$ & $\begin{array}{l}\text { Vatandaşların ve sosyal paydaşların KÖSO projelerinde ne derece yer aldıklarını, } \\
\text { bunların hangi faktörleri hesaba kattığını, projelerin performans ve yenilikçiliği } \\
\text { üzerindeki etkilerini incelemişlerdir. Bunun için de Hollanda'daki KÖSO projelerine } \\
\text { katılan } 144 \text { katılımcı ile anket çalışması yürütülmüștür. }\end{array}$ \\
\hline Tekin (2017) & $\begin{array}{l}\text { KÖSO yöntemini kullanan ülkelerin deneyimlerine değinen araştırmacı, Türkiye'deki } \\
\text { sağlık sektörü uygulamalarına ilişkin genel bir değerlendirme sunmuștur. }\end{array}$ \\
\hline Yusufoğlu (2017) & $\begin{array}{l}\text { Avrasya Tüneli, Osmangazi - Yavuz Sultan Selim Köprüleri ve bu projelere yönelik } \\
\text { hazinenin koşullu yükümlülüklerini mali risk açısından değerlendirmiştir. }\end{array}$ \\
\hline $\begin{array}{l}\text { Ayhan ve Önder } \\
\text { (2018) }\end{array}$ & $\begin{array}{l}\text { Türkiye'de KÖSO ile yapılan entegre sağlı kampüslerinin mevzuat boyutu } \\
\text { derinlemesine görüşme yöntemi kullanılarak araştırılmıștır. }\end{array}$ \\
\hline
\end{tabular}

Kaynak: Yazar tarafindan oluşturulmuştur. 


\section{YURT YAPIMINDA KAMU ÖZEL SEKTÖR ORTAKLIĞI MODELİ}

KÖSO modeli ile birçok ülkede sağlık, ulaşım, altyapı, enerji, savunma, turizm, eğitim, adalet gibi alanlarda hizmetlerin üretildiği görülmektedir. Türkiye'de de benzer şekilde kamusal projelerin üretilmesinde yapılan sözleşme bedelleri değerlendirildiğinde (Tablo 1); ulaşım, enerji, sağlık tesisleri yatırımı ve limanların olduğu görülmektedir. Ancak 16.08.1961 tarih ve 351 sayılı Yüksek Öğrenim Kredi ve Yurtlar Kurumu Kanununun 20. maddesine, 25.11.2010 tarihinde, 6082 sayılı Kanunla tıpk1 Sağlık Hizmetleri Temel Kanununda olduğu gibi bir madde eklenmesi yoluyla yurt binası ve tesislerinin kiralama karşılığ yaptırılması yöntemi eklenmiştir (Kalkınma Bakanlığı, 2014: 32-33). Bu sayede yurtların yapılması için bu modelin kullanılmasının kapıları açılmıştır. Bu kapsamda, 351 sayılı kanunun 20. maddesine eklenen fikralar ile yurt yapımına ilişkin temel ifadeler yer almaktadır. Bu maddelerin içeriği ise şöyledir;

"Yapılmasinın gerekli olduğuna Yüksek Planlama Kurulu tarafindan karar verilen yurt binasi ve tesisleri; Kurumca belirlenecek proje ve temel standartlar çerçevesinde, mülkiyeti kendisine, Kuruma ya da Hazineye ait olup Kuruma tahsis edilen taşınmazların üzerinde ihale ile belirlenecek gerçek veya özel hukuk tüzel kişilerine kırkdokuz yıl geçmemek şartıyla belirli süre ve bedel üzerinden kiralama karşılı̆̆ yaptırılabilir.

Bu amaçla, üzerinde bina ve tesis yapılacak Hazineye ait taşınmazların üzerinde Kurumun talebi üzerine Maliye Bakanlı̆̆ınca, Kuruma ait taşınmazların üzerinde ise Kurumca gerçek veya özel hukuk tüzel kişileri lehine kırkdokuz yılı geçmemek şartıyla kira süresi kadar bedelsiz olarak bağımsız ve sürekli nitelikli üst hakk tesis edilebilir. Bu taşınmazların tapu kütüğüne; üst hakkına konu taşınmazların üst hakkı süresince amacı dışında kullanılamayacă̆ına, Maliye Bakanlığı ve Başbakanlık veya Kurumun bağll olduğu Bakanlıktan izin alınmaksızın devredilemeyeceğine dair şerh konulur.

Kira bedeli ve kiralama süresinin tespitinde; taşınmazın gerçek veya özel hukuk tüzel kişilerine ait olup olmadiğl, Kuruma veya Hazineye ait taşınmazlar üzerinde bedelsiz olarak üst hakkı tesis edilip edilmediği, yatırımın maliyeti, kiralama konusu taşınmazın ve üzerindeki tesislerin bir kısmının veya tamamının işletilmesinin kiralayana verilip verilmeyeceği hususları dikkate alınır.

$\mathrm{Bu}$ şekilde yapılacak kiralama işlemlerine ait kira bedelleri Kurumun bütçesinden ödenir." (351 sayılı Kanun, Ek fikralar: 25/11/2010-6082/9 md.).

Söz konusu ifadelerden anlaşılacağı üzere ilgili maddeler kapsam olarak oldukça dar çerçevede bilgiler sunmaktadır. Bu da KÖSO modeli ile yaptırılan yurtlara ilişkin daha geniş çapta bilgi edinilmesi ve uygulamadaki durumun gözlemlenmesi ihtiyacını doğurmaktadır.

\section{KAMU ÖZEL SEKTÖR ORTAKLIĞI MODELİ İLE KIRALANAN KREDİ YURTLAR KURUMU YURTLARI ÜZERINE NITEL BİR ALAN ARAŞTIRMASI}

KÖSO ile devletlerin sunacağı mal ve hizmetlerin, yapım işlerinin bütçe yetersizliği nedeniyle ertelenmesinin veya yapılamamasının önüne geçilmesi hedeflenmektedir. KÖSO'nun temel amacı ise yatırım finansmanı olmak üzere, kamu yatırımlarından kaynaklanan maliyetlerin azaltılması, özel sektörün sağladığı hizmetlerdeki konforunun kamu hizmetinde de yaşatılması, riskin etkin dağıtılması gibi faydalar doğurmaktır. Bu nedenle bu çalışmada KÖSO modeli ile yürütülen KYK yurtlarındaki süreç incelenmiştir. Bunun içinde nitel araştırma yöntemi kullanılmış, Çanakkale'de KYK yurtları yönetiminde bulunan ve sürecin içerisinde aktif rol oynayan kişilerle derinlemesine görüşmeler yapılmıştır. 


\subsection{Araştırmanın Amacı}

KÖSO ile kiralanan yurtların özellikleri, nitelikleri, ortaya çıkardığı etkiler, olumlu ve olumsuz yanları gibi etkilerinin KYK yöneticileri ile derinlemesine görüşme yöntemi kullanılarak araştırılması amaçlanmıştır. Bu bağlamda genel olarak aşağıdaki sorulara yanıt aranmıştır. Bu sorular;

- Ne ifade ettiği / mahiyeti / mantı̆̆ / diğer yurtlardan farkının ne olduğu,

- Avantajlarının neler olduğu,

- Dezavantajlarının neler olduğu,

- Kira maliyetlerinin nasıl hesaplandığı,

- Kamuoyunun bilgi düzeyi,

- Özel sektöre ne tür faydalar sağladığ1,

- Özel sektörün karşılaştı̆̆ risklerin neler olduğu,

- Kamuya ne tür yararlar sağladiğı,

- Kamunun karşılaştığı risklerin neler olduğu,

- Hukuki ve mali denetimlerin nasıl olduğu ve,

- KYK yöneticilerine sormayı unuttuğumuz ancak görüşme kapsamında önemli olduğunu düşündükleri konular hakkındaki fikirleri oluşturmuştur.

\subsection{Araştırmanın Önemi}

Türkiye, KÖSO modelini ilk uygulayan ülkelerden biri olmasına rağmen yurtların kiralanmasında bu modelin kullanılması ancak 351 sayılı kanuna 2010 senesinde eklenen ek fikralar ile sağlanmıştır. Literatür taraması kapsamında KÖSO modeli ile kiralanan yurtlara yönelik çalışmaların sayısının oldukça az olması, Çanakkale'de faaliyet gösteren $10 \mathrm{KYK}$ yurdunun 6'sının KÖSO ile kiralanmış olması ve nitel araştırma kapsamında bu durumun değerlendirilmesi çalışmanın önemini arttırmaktadır.

\subsection{Araștırma Alanı}

Araştırma, Çanakkale ilinde yapılmıştır. Çanakkale ilinin seçilmesinde en önemli etken KÖSO modeli ile kiralanan birçok yurdun bulunması olmuştur. Nitekim Çanakkale'de bulunan 10 adet yurdun 6 tanesi KÖSO modeli ile kiralanmıştır. KÖSO kapsamında faaliyet gösteren yurtları belirtmek gerekirse; Biga Ahmet Bican Erkek Öğrenci Yurdu, Gelibolu Kız Öğrenci Yurdu, Terzioğlu Kız Öğrenci Yurdu, Safiye Hüseyin Kız Öğrenci Yurdu, Nusrat Erkek Öğrenci Yurdu ve Kerime Sultan Erkek Öğrenci Yurdu şeklindedir.

\subsection{Araştırma Yöntemi}

Araştırmada öncelikle literatür taraması kapsamında KÖSO modeliyle kiralanan yurtlara ilişkin genel teorik çerçeve çizilmiştir. Teorik çerçeve sonrasında modelin sağladığı avantajlar ve dezavantajlar ifade edilmeye çalışılmıştır. Elde edilen bulgular ışı̆̆ında KÖSO modeli ile kiralanan yurtlara ilişkin sürdürülebilirlik noktasında bir fikir sunulmaya çalışılmıştır. Bu kapsamda nitel araştırma yöntemi ile bu konuda deneyim sahibi olan kişilerin fikirlerinden faydalanılmaya çalışılmıştır. Çünkü sosyal bilimciler, sosyal yaşam hakkında bilgi edinmek için büyük ölçüde sözlü görüşmelere güvenmektedirler (Taylor vd., 2016: 102).

Nitel araştırma, bireylerin dünyayı nasıl gördüklerini ve yaşadıklarını incelemek amacıyla spesifik yöntemlerin kullanıldığı belirli bir konunun insani unsurlarını keşfetmek üzere tasarlanmıştır (Given, 2008: xxix). Bu yöntem, kendi bağlamında yaşanmış deneyimlere odaklanarak katılımcı bakış açılarını ve hikâyeleri yorumlamaktadır (Tracy, 2013: 5). Bu kapsamda görüşmelerde açık uçlu sorular sorulmuş ve kişilerin deneyimleri, algıları, fikirleri, duyguları ve bilgileri ile ilgili derinlemesine cevaplar alınması sağlanmıştır. Veriler 
yorumlamanın yapılabilmesi için bağlamı yeteri derecede yansıtan doğrudan alıntılar içermektedir (Bütün ve Demir, 2014: 4).

\subsection{Araştırmanın Evren ve Örneklemi}

Araştırmada amaca uygun örneklem oluşturulmaya dikkat edilmiştir. Bu kapsamda, rastlantısal olmayan örneklem seçilmiştir. Örneklem oluşturulurken, KYK yöneticilerinden ulaşılabilenlerin hepsi ile görüşme yapılması hedeflenmiştir. Ancak Çanakkale genelinde 6 adet olan kiralık yurttan 3'ünün yöneticisi ve T.C. Gençlik ve Spor Bakanlığı Yüksek Öğretim Kredi ve Yurtlar Kurumu Çanakkale İl Müdürlüğü İdari İşler ve İnşaat Emlak Şube Müdürü ile görüşme yapılmıştır.

\subsection{Araştırma Etiği}

Derinlemesine görüşmeler yapılmadan evvel görüşülen kişilere çalışmanın mahiyeti hakkında ön bilgiler verilerek, araştırmanın amacı açıklanmış, görüşme esnasında kayıt cihazı ile isimlerinin kullanılacağı bilgisi verilmiştir. Görüşülen kişilerin istememesi halinde ses kayıt cihazı ya da isimlerinin kullanılmayacağı özellikle belirtilmiştir. Görüşmecilere görüşmeyi istedikleri zaman sonlandirabilecekleri ya da görüşmeden tamamen vazgeçebilecekleri belirtilmiştir. Ayrıca görüşme kapsamında elde edilen bilgilerin daha sonra çalışma ile ilgili akademik yayınlarda kullanılabileceği bilgisi de verilmiştir.

\subsection{Araştırmanın Sınırlılıkları ve Kolaylaştırıcıları}

Derinlemesine görüşmeler yapılırken karşılan sorunlar genellikle; para, zaman ve enerji olarak ifade edilmektedir. Nitekim bu çalışma yürütülürken de yurtların il merkezi ve ilçelerde olması nedeniyle zaman, enerji ve para konusunda bir takım sorunlarla karşılaşılmıştır. Görüşmeler esnasında bazen yönlendirme, bazen de önceden planlanmayan bir kişi ile mülakat yapılması ise çalışmanın kolaylaştırıcı yanını oluşturmuştur. Sonuç olarak Çanakkale'de bulunan KÖSO modeli ile faaliyete geçen 6 yurdun 3'ünün yöneticisi ve KYK Çanakkale İl Müdürlüğünden 1 şube müdürü ile görüşülerek konusunda uzman olan bu kişilerin yaşanmış deneyimleri, diğer bir ifade ile katılımcı bakış açıları ve hikâyeleri ortaya çıkarılmıştır.

\subsection{Araştırmada Veri Analiz Tekniği}

Yapılan derinlemesine görüşmelerle, açık uçlu sorular sorularak, görüşmecilerin deneyimleri, algıları, fikirleri, duyguları ve bilgileri ile ilgili derinlemesine cevaplar alınması sağlanmıştır (Bütün ve Demir, 2014: 4). Görüşmeler sonucunda elde edilen veriler anlamlı bölümlere ayrılmış, araştırmanın amaçlarına göre analitik bir sınıflandırmaya tabi tutulmuştur. Bir soruya verilen farklı yanıtların dökümü yapılarak analiz edilmiştir. Verilen yanıtların özgünlüğünü korumak adına kodlama sürecine büyük bir özen gösterilmiştir.

\subsection{Bulgular}

Görüşmelerde, görüşmecilere Çanakkale'de faaliyet gösteren KÖSO modeli ile kiralanan KYK yurtlarına ilişsin 11 tane açı uçlu soru sorulmuştur. 11. soru, sorulması unutulan ancak görüşme kapsamında önemli olduğu düşünülen şeylerle ilgili olduğundan, ilk 10 soruya verilen yanıtlar içerisinde değerlendirilmiş̧tir.

\section{- Ne ifade ettiği / mahiyeti / mantığı / diğer yurtlardan farkının ne olduğu,}

KÖSO modeli ile kiralanan KYK yurtlarının kamuya ait diğer KYK yurtlarından hiçbir farkı bulunmamaktadır. Bu yurtlar kamuya ait KYK yurtlarından farksız olduklarından KYK Genel Müdürlüğü ve İl Müdürlüğü'nce belirlenen yönetmelik ve talimatlara göre idare edilmektedir. KÖSO modeliyle kiralanan KYK yurtları, işleyişleri bakımından KYK genel standartlarına göre belirlenen ölçülerde ve projelere göre yaptırılmaktadır. Bu kurumların işletilmesi KYK mantığında sürdürülmektedir. 
Yurt ihtiyacinın doğması durumunda KYK Genel Müdürlüğü'nce duyuru yapılmaktadır. Başvurmak isteyen sermayedarlar gerekli prosedürleri yerine getirerek başvuru yapmaktadırlar. Bu kapsamda ön protokol imzalanmakta ve inşa faaliyetine başlanmaktadır. Ön protokolle yurdun sıfırdan yapılması modelinin yanı sıra birde hazır binaların kiralanması usulü de uygulanmaktadır. Çanakkale' de yer alan kiralık yurtların 3'ü ön protokolle (Safiye Hüseyin, Nusrat ve Kerime Sultan Öğrenci Yurtları) yaptırılmışken; 3 tanesi de hazır bina (Biga Ahmet Bican, Gelibolu ve Terzioğlu Öğrenci Yurtları) olarak kiralanmıştır.

$\mathrm{Bu}$ model ile kiralanan yurtlara devlet tarafından bir bütçe ayrılmayıp doğrudan özel sektör yatırımcısı tarafından yaptırılmakta, KYK Genel Müdürlüğ̈’nce kira sözleşmesi yapılarak 15 yıllığına kiralanmaktadır. 15 yıllık süre dolduğunda ise sözleşmenin yenilenmesi yetkisi KYK Genel Müdürlügü̈'ne aittir. Yurdun iç bölümünde yer alan malzeme ve eşyalar ise KYK'ya aittir. Ancak daha sonraki kiralamalarda kurum stratejisi gereği bina içindeki malzemelerinde kiralanması planlanmaktadır. Süre sona erdikten sonra sözleşme yenilenmeyecekse mülk sahibi kendi binasının sahibi olmaya devam etmektedir. Bu da KÖSO ile yaptırılan yurtlarda Yap-Kirala modelinin geçerli olduğunu göstermektedir. Yapılan görüşmelerde bu şekilde kiralanan yurt sayısının tüm KYK yurtlarının sayısının \%50'si dolaylarında olduğu ifade edilmiştir. Ayrıca yurt kapasitelerinin ilin ihtiyacına göre belirlenmekte olduğu ve 500 sayısının altına düşülmemeye çalışıldığı ifade edilmiştir. Nitekim KYK Ön Protokolü ve Kira Sözleşmesi'nde de bazalı sistemle illerde 750 ilçelerde ise 300 sayısının üzerinde olması gerektiği ifade edilmiştir.

\section{- Avantajlarının neler olduğu,}

Gerçekleştirilen derinlemesine görüşmeler neticesinde, KÖSO modeli ile kiralanan bu yurtların birçok avantajının olduğu ifade edilmiştir. "Devlete ait KYK yurdu olduklarından bu yurtların belli bir hizmet standardı (güvenlik ve ekonomiklik gibi) var. Devlet inşaat aşamasiyla ilgili bir sorun olduğunda bina sahibini sorumlu tutuyor. Bina tesliminde yaşanacak gecikmeler için ise geciken gün başına belirlenen bir ceza kesilip bu tutar kiradan düşülüyor" (KYK Yurt Yöneticisi X). "Oda içerisinde yer alan banyolar, çalışma masaları ögrencilerin avantajınadır" (KYK Yurt Yöneticisi Y). "Kapasiteyi arttırdı. O da çok önemli bir durum. Sosyal devlet anlayışına uyuyor" (KYK Yurt Yöneticisi Z).

"Bina inşaatından kaynakl sorunlar müteahhit firmalara yaptırllmakta. Ancak kullanim kaynakl sorunlar kurum tarafindan gideriliyor. Aksi durumda kiradan kesme ve cezai müeyyideler var. Devlet bina yapım sürecinde kullanılacak personel giderlerine ve sabit yatırım maliyetlerine katlanmıyor. Devletin 5-6 yılda yaptırdı̆̆g yurtları özel sektör çok daha kisa sürede yaptı. Ayrıca 2013 yılında 350 bin olan yurt kapasitesi 2018 yllına gelindiğinde 880 bine çıktı. Bu da devletin bu alanda önemli bir atılım yapmasina ve hızl bir büyüme yakalanmasına olanak sağladl. Çünkü yurt yapım maliyetleri normal inşaat faaliyetlerine göre 4 kat daha maliyetli ve Türkiye'nin lokomotif sektörü inşaat sektörü olduğundan dolayı önemli bir büyüme să̆landı. Öğrenciyi almadan kira ödemesi yapmıyoruz. Kamu kaynă̆ıyla böyle bir kapasiteye ulaşmak oldukça zordu” (KYK Şube Müdürü T).

\section{- Dezavantajlarının neler olduğu,}

Bu model ile kiralanan yurtların avantajlarının yanı sıra birçok noktada dezavantajları da söz konusudur. Bunlar; "Bu model ile yapılan yurtlarda bina teslim edildikten sonra bina ile ilgili yaşanan sorunlar (çatı, kanalizasyon, elektrik vs.), aylık kira bedellerinin yüksek olmasl, yurdun konum olarak elverişsiz olmasl, yurt kapasitesini arttırmak adına elverişsiz odaların kullanılması, özellikle de enflasyon olduğunda kira artışlarının yüksek olması, binanın devlet tarafindan yapılmasl durumunda daha uzun yıllar kullanılmasi durumu, yurt kapasitesinin boş kalması durumunda tam kapasite üzerinden ödenen tutarlar" olarak ifade 
edilmiştir. Ayrıca "Belediye sınırlarının dışında yurt yapılması öğrencilere zaman ve para noktasında bazı olumsuzluklar doğurmakta. Yine alt yapıya yönelik bazı sorunlar meydana gelmektedir" (KYK Yurt Yöneticisi X).

"Bu yurtlarda alan sinırlı olup, eski KYK yurtlarında olan spor salonu, toplantı salonu ve etüt salonları gibi sosyal donatı alanları oldukça kısıtll, yurtlar tam hazır olmamasına rağmen açıllşlarının yapılması ve inşaat faaliyetlerinden kaynaklı sorunlar yaşıyoruz. Bu tür yurtların yapımında devletin bizzat rol oynaması lazım” (KYK Yurt Yöneticisi Y).

Yine benzer bir görüş, bir başka yurt yöneticisi tarafından vurgulanmıştır; "Yap-KiralaDevret olsaydı çok daha iyi olurdu. Bu şekilde hiçbir mantığı yok. Sosyal donatı alanları kısıtlı olduğu için kendi çabalarımızla gidermeye çalışlyoruz. Terzi, manav, kırtasiye yok, öğrenciye en çok lazım olan şey fotokopi, yok. Yine kütüphanemiz yok. Plansılılk mevcut. Tip proje gerçekleştirilmeli. Devletten alınan kiralarla ortalama 10 sene içinde yatırım kendini amorti ediyor daha sonrast tamamen kazanç. Kira süresi bittikten sonra da binalar sermaye sahibine kalıyor. Maliyetleri düşürmek için bina malzeme ve işçilik kalitesi düşük. Devlet mutlaka olmalı" (KYK Yurt Yöneticisi Z).

KÖSO kapsamında yapılan yurtlarda karşılaşılan bir başka sorun ise gelecekte muhatap bulamama ve planlama noktalarında olduğu görülmüştür. Şube Müdürü T'nin ifadesi şöyledir; "Imalat kaynaklı sorunlar olmakta. Burada da mihenk noktamız yapım kaynaklı mı olduğu ya da kullanım kaynaklı olduğu mu noktaları. Enflasyon sürecinde kiraların artması ile binaların kendini amorti etme süresi kısaldl. Bu durum da amorti süresinde bazı sapmalar doğuruyor. Ortalama 7-8 yllda kendini amorti ediyor bu binalar. Bazen de yerelde bu denli yüksek yatırımları yapma gücüne sahip firmalar bulmak zor. Bu güce sahip olmayan firmalarla çalışıldığında ileride muhatap bulamamakla ilgili bazı sorunlar doğabilmekte. Yanlış planlama, kapasitenin doldurulamaması ve ara dönemlere denk gelme durumları bizim için dezavantaj olabilir” (KYK Şube Müdürü T).

\section{- Kira maliyetlerinin nasıl hesaplandığı,}

Yapılan görüşmeler neticesinde KYK yöneticileri, kira bedelinin öğrenci sayısına göre belirlendiğini ifade etmiştir. Kira bedellerinin belirlenmesine ilişkin daha detaylı bilgi ise KYK Şube Müdürü T tarafından şu şekilde ifade edilmiştir;"Yurtların kira maliyetleri ögrenci kapasitesine göre KYK Genel Müdürlüğü'nce belirlenmekte. Kira bedeli belirlenirken yurdun ögrenci kapasitesine göre bir meblağ hesaplanıyor. Bu meblağ öğrencinin ödediği $258 \mathrm{TL} / a y l ı k$ ücretin (2018 yılı itibariyle) \%70 'ini aşmamak üzere pazarlık usulüyle gerçekleştiriliyor”.

\section{- Kamuoyunun bilgi düzeyi,}

Görüşmecilerin tamamı kamuoyunun bu model ile kiralanan yurtlar hakkında yeterli bilgiye sahip olmadığ 1 noktasında hem fikir olmuştur. Genellikle inşaat işiyle ilgilenenler ya da bu işe istekli olan kesimler bu yurt modeli ile ilgilenmektedir. Halkın büyük çoğunluğu bu model hakkında yeterli bilgi sahibi değildir.

\section{- Özel sektöre ne tür faydalar sağladığı,}

KÖSO modeli ile kiralanan yurtların özel sektöre önemli faydaları bulunmaktadır. Görüşmeciler bu faydaları şöyle ifade etmiştir; "Yurt binaları, özel sektör tarafindan yapılmakta, devlet bankaları ve özel bankalar imzalanan ön protokollere kolaylıkla kredi vermektedir. Ayrıca özel sektör için bu yurtlarda devletin kiracı olması mülk sahibine oldukça önemli garanti olmuştur. Aylık yurt kiraları oldukça yüksek. Bu miktarlar yurt kapasitesine göre belirleniyor ve kapasitenin doluluk düzeyi bu miktarı düşürmüyor" (KYK Yurt Yöneticisi $\mathrm{X).} \mathrm{"Yapılaşmanın} \mathrm{daha} \mathrm{kısitlı} \mathrm{olduğu} \mathrm{yerlerde} \mathrm{yapılan} \mathrm{yurtlar,} \mathrm{yapıldıktan} \mathrm{sonra}$ çevrelerindeki yapılaşmayı da arttırıyor. Çevresine de bu yönüyle fayda sağlıyor” (KYK Yurt 
Yöneticisi Y). "KYK alım olarak askeriyeden sonra en fazla alımı gerçekleştiren ikinci kurum. Bu model ile toplu alım yapma noktasındaki avantajını özel sektöre devretti. KYK yurtları kalite standartları bakımından M1 (en iyi olmak üzere), M2 ve M3 kategorilerine ayrllmakta. Bu modelde özel sektör yatırımcıları kira getirisi daha yüksek olan standardı yüksek M1 yurtlarını yaptırmak niyetinde. Çanakkale'de yer alan 6 kiralık yurttan 5'i M1 iken 1 tanesi M2'dir. Bu da iyi kalitede yapılan yurtların kira bedellerinin de yüksek olması demek" (KYK Şube Müdürü $\mathrm{T})$.

\section{- Özel sektörün karşılaştığı risklerin neler olduğu,}

Görüşmeciler riskleri şöyle ifade etmiştir; "Özel sektör bina yapım aşamasında müteahhitlik alanında bazı risklerle karşı karşıya. Belirlenen süreler içerisinde binanın teslim edilmemesi durumunda gün başına para cezası ödenmekte” (KYK Yurt Yöneticisi X). "Bazı yurtlarda bina tesliminden sonraki 5 sene içinde bina ile ilgili eksikliklerin giderilmesi taahhüdü var. Bu durum bina inşaata yeterince özen göstermeyen özel firmalar için önemli bir risk. Ruhsat alamama, inşaat maliyetleri, bölümün daralması ya da üniversitenin kapanması halinde devletin sözleşmeyi tek taraflı fesih hakkı var. Teslimatta problem olması durumunda kirayı başlatamama ve bir takım cezai müeyyideler uygulanmast olabilir" (KYK Yurt Yöneticisi Y). "Risk yok, belki müteahhitlik ile ilgili sorunlar olabilir" (KYK Yurt Yöneticisi $\mathrm{Z})$.

\section{- Kamuya ne tür yararlar sağladığı,}

Görüşmeciler KÖSO ile kiralanan yurtların kamuya olan yararlarını şöyle ifade etmiştir; "Binanın tamamlanma süreci ile ilgili harcamalar özel sektör tarafindan, tamamen kendileri takip ediyor. Böylece yurt binalarının yapımı için devlet kaynak ayırmamış ve bu maliyetten kurtulmuş oluyor. Devletin bu modelle yurt yapımına girişmesi, devlete yurdun yapımı ile ilgili hiçbir riske girmemesi demek. Bu alana herhangi bir ödenek tahsis edilmesine gerek yok. Istihdam yaratma olanağl oluşuyor. Yatırımlar artmakta” (KYK Yurt Yöneticisi X).

Devletin kaynak ayırmadan gerçekleştirmiş olduğu bu yurtlar aynı zamanda özel sektör tarafindan yapılarak önemli bir zaman avantajı da doğurmuştur. Bu durumu KYK Yurt Yöneticisi Y şöyle ifade etmiştir; "Devletin bu model ile yurt yapımına geçmesi ilk aşamada devlete yurt yapımında önemli bir potansiyel sağladı ve bir anda devletin arzu ettiği yurt kapasitesine ulaştı". Ayrıca "Bu model ile yurt yapımının sürdürülmesi ile birçok ögrenciye barınma imkânı sağlanmış ve ögrencilerin olumsuz yönlere sevk olması önlendi” (KYK Yurt Yöneticisi Y).

"İnşaat yönünden hasarları müteahhitlere yaptırıyoruz. Mecburlar. Kiradan kesme durumu var. Sözleşme var. Ruhsatlar onlara ait. Personel kazancı var. Hizlı üretiliyor bu binalar. 5-6 yılda biz yapıyoruz. Ön protokolle bu süre çok kısaldı. \%50'si bu şekil. 3 yılda kapasite \%100 arttı. Hızlı bir büyüme yakalandı" (KYK Şube Müdürü T).

\section{- Kamunun karşılaştığı risklerin neler olduğu,}

Görüşmecilerin tamamı devletin bu yurtlarda öğrenci kapasitesine göre aylık kiralama bedelinin ödenmesi taahhüdü bulunduğunu ifade etmişlerdir. Bu taahhüdün dişında bir mali yükümlülüğün olmadığını ifade etmiş̧lerdir. Ancak yurt yöneticisi olan 3 görüşmeci uzun vadede kiraların yükselme eğiliminde olmasının bu model ile yurt kiralanmasının sürdürülebilirliğini tehlikeye sokabileceğini vurgulamıştır. Çözüm noktasında ise farklı öneriler söz konusu olmuştur;

"Devletin bu tür yurtları yapmaya kudreti yeter. Yurt işinin özel sektöre bırakılması bina tesliminden sonra bina ile ilgili birçok sorunun doğması demek. Bu nedenle bu yurtlarla ilgili genel kanı özel mülkiyetten ziyade devlet kurumlarınca sürecin yürütülmesi lazım” (KYK 
Yurt Yöneticisi Y). "15 sene sonra bina devletin olsa mantıklı. 2 senede verilecek kira parasıyla yurt yapılır. Öğrenci rahatlar” (KYK Yurt Yöneticisi Z). "KYK'nın öğrenci karşılama oranı Türkiye bazında \%11-12 dolaylarında iken Çanakkale'de bu oran \%17-18 dolaylarında. Ancak bu yöntemle yurt yapımı bir doygunluğa ulaşmış bu nedenle de ileriki yıllarda KYK kendi bütçesinden yurt yapımına devam edecek. Kira artışlarını iyi yönetmek ve bütçe dengesini iyi korumak lazım. Aksi takdirde ödeme ile ilgili sorunlar doğacak. Yap-KiralaDevret modeli uygulansaydı kiralar daha yüksek olacaktı" (KYK Şube Müdürü T).

\section{- Hukuki ve mali denetimlerin nasıl olduğu,}

Görüşmeciler hukuki ve mali denetimler konusunda şu ifadeleri kullanmışlardır; " $K Y K$ Il Müdürlüğü'nce ayda bir, KYK Genel Müdürlügü müfettişlerince ise üç yılda bir genel mali ve idari denetime tabiyiz" (KYK Yurt Yöneticisi X). "Ill Müdürlüğü'nün diyetisyenleri ayda bir, genel müdürlükten ise 2 senede 1 denetim oluyor" (KYK Yurt Yöneticisi Z). "15 yzllık kiralama sürecinde yapımdan kaynaklanan tüm sorunlar müteahhit firmaya ait. Bu noktada devlet maliyet bedelinin \%6'sı dolayında bir teminat mektubu almakta" (KYK Şube Müdürü $\mathrm{T})$.

\section{SONUÇ VE ÖNERİLER}

KÖSO modeli ile yurtların kiralanmaya başlanması Türkiye' de yeni bir durum olmasına rağmen KYK yurtlarına oranı toplamda \%50'lere yaklaşmıştır. KÖSO ile yapılan yurtların sayıca artması ise beraberinde olumlu yanları ile birlikte olumsuz yanlarının da sorgulanmasını gerektirmektedir. Bu çalışmada KÖSO modeli ile Çanakkale'de faaliyete geçen KYK yurtlarındaki süreç ele alınmıştır. Görüşmelerden elde edilen bulgulara göre; bu model ile yaptırılan yurtların kamuya ait diğer yurtlardan hiçbir farkı bulunmamakta ve bu yurtlar KYK Genel Müdürlüğü ve İl Müdürlüğü'nce belirlenen yönetmelik ve talimatlara göre idare (KYK Yurt Yöneticisi X) edilmektedir. Ayrıca yurt binalarının özel sektöre yaptırılması veya mevcut binaların kiralanması usulünün benimsendiği görülmektedir.

Gerçekleştirilen derinlemesine görüşmeler neticesinde, KÖSO modeli ile kiralanan yurtların ortaya çıkardığı birçok avantaj ve dezavantajın bulunduğu görülmektedir. Avantaj olarak; devletin arzu ettiği kapasite artışına kısa sürede ulaşılması, inşaat sektörüne olan katkıları, müteahhitlik ile ilgili sorunlara maruz kalınmaması, kısa vadede maliyet kazanc1, personel giderinin azalması, bu modelle kiralanan yurtların daha kısa sürede inşa edilmesi ile zamandan tasarruf edilmesi ve ekonomik büyümeye katkı sağladığı söylenebilir. Nitekim yurt inşaatından kaynaklı sorunların müteahhit firmalara yaptırılması, devletin 5-6 yılda yaptırdığ yurtları özel sektörün çok daha kısa sürede yapması (2013 yılında 350 bin olan yurt kapasitesinin 2018 yılına gelindiğinde 880 bine çıkması), devletin bu alanda önemli bir atılım yapmasına ve hızlı bir büyüme yakalamasına olanak sağladığı görülmektedir. Ayrıca bu yurtlar ile özel sektöre; kira garantisinin sağlanması, iş hacmi ve istihdam olanaklarının arttırılması gibi faydaları söz konusudur.

KÖSO kapsamında kiralanan yurtların avantajların yanı sıra birçok dezavantajının olduğu da görülmektedir. Yurtlara taşındıktan sonra bina yapımından kaynaklı yaşanan problemler, aylık kira bedellerinin yüksek olması, binaların devlet tarafından yapılması durumunda daha uzun yıllar kullanılması durumu, enflasyonist dönemlerde kira artış oranlarının yüksek olması, yanlış planlama yapılması durumunda yurt kapasitesinin boş kalması sonucu oluşacak maliyetler, bazı yurtlarda sosyal donatı alanlarının kısıtlı olması, YapKirala-Devret modeli yerine Yap-Kirala modelinin uygulanıyor olması ve sermaye noktasında güçlü firmalarla çalışılmaması durumunda ise ileride muhatap bulamama gibi birtakım dezavantajları bulunmaktadır. 
KÖSO modeli ile kamunun elde ettiği avantajlar oldukça önemlidir. Ancak dezavantajlarının giderilmesi bu modelin etkinliğini arttıracaktır. Yapılan görüşmelerden elde edilen bulgulara ek olarak literatürde de ifade edildiği üzere kriz sonrası dönemde maliyetlerin artması, ölçek getirisinden kamunun yararlanamaması, maliyetlerin zamansal dağılımı ve tesislerin bakım onarım sorunu, modelin kamu gelirlerini tahrip edici boyutu ve maliyet sorunu gibi birtakım sorunları söz konusudur. Elbette ki söz konusu yurtların bu modelle kiralanmasının ekonomik başta olmak üzere birçok avantajı bulunmaktadır. Ancak ortaya çıkardığı olumsuzlukların giderilmesi ve bu modelin bir noktada revize edilmesi faydalı olacaktır. Söz konusu olumsuzluklarının giderilmesi amacıyla aşağıdaki önerileri sıralamak mümkündür;

- KYK tarafindan kiralanan yurtlara taşınma sonrası dönemlerde ortaya çıkan sorunları minimize edecek sözleşme yapılarının oluşturulması,

- Özel sektörün kurumsal kalitesinin geliştirilmesi,

- Özel sektörün yurt yapımı konusundaki taleplerinin toplanması sürecinde duyuru usulünden ziyade ihale sürecine ağırlık verilmesi,

- Yurt binalarının teslim alınmasından sonraki süreçte yapılan denetimlerin daha etkin hale getirilmesi,

- KÖSO mevzuatının tek çatı altında toplanması,

- Yurt kapasiteleri ile ilgili planlamanın sağlıklı yapılması ve koordinasyon sorununun ortadan kaldırılmas1,

- Yurtların kiralanmasında kullanılan Yap-Kirala yönteminin yanı sira Yap-KiralaDevret yönteminin de değerlendirilmesi ve,

- Enflasyonist süreçlerde ortaya çıkan yüksek kira artışlarına limit getirilmesi KÖSO modeli ile kiralanan yurtların söz konusu dezavantajlarını azaltmak adına önemli olacak ve modelin sürdürülebilirliğine önemli katkıda bulunacaktır. 


\section{KAYNAKÇA}

ACARTÜRK, E. ve KESKİN, S., (2012), Türkiye'de Sağl1k Sektöründe Kamu Özel Ortaklığ1 Modeli, Süleyman Demirel Üniversitesi İktisadi ve İdari Bilimler Fakültesi Dergisi, 17 (3), 25-51.

ALAGÖZ, M. ve YOKUŞ, T., (2017), Kamu Özel İşbirliği (KÖİ) Yatırımları ve Ekonomik İllüzyon Etkisi, KMÜ Sosyal ve Ekonomik Araştırmalar Dergisi, 19 (32), 115-122.

ALEXANDERSSON, G. and HULTÉN, S., (2007), Prospects and Pitfalls of Public-Private Partnerships in the Transportation Sector - Theoretical Issues and Empirical Experience, International Conference Series on Competition and Ownership in Land Passenger Transport - 2007 - Hamilton Island, Queensland, Australia.

ASSOCIATION OF CONSULTING ENGINEERING COMPANIES (ACEC), (2010), Understanding Public Private Partnerships in Canada.

AYHAN, E. ve ÖNDER, E., (2018), Türkiye'de Sağlık Sektöründe Kamu Özel Ortaklığ1 Modeli, Uluslararası Sağlık Yönetimi ve Stratejileri Araştırma Dergisi, 4 (1), 514-526.

BERKSOY, T. ve YILDIRIM, N. E., (2017), Kamu Özel Ortaklıkları ve Uygulamaya İlişkin Bir Anket Çalışması, Journal of Life Economics, 4 (2), 141-166.

BÜTÜN, M. ve DEMİR, S. B., (2014), Nitel Araştırma ve Değerlendirme Yöntemleri, (Michael Quinn Patton, 3. Baskıdan Çeviri), Ankara: Pegem Akademi.

CENTER FOR DISEASE CONTROL AND PREVENTION (CDC), (2018), CDC's Guiding Principles for Public-Private Partnerships: A Tool to Support Engagement to Achieve Public Healt Goals, Public-Private Partnerships and CDC.

CHISA, O. S., OJO, V. K., IKENI, N. O. and GAMBO, A. A. I., (2015), Public-Private Partnership (PPP) As Catalyst for Sustainable Infrastructual Development (Effort of Rivers, Cross Rivers, Oyo and Lagos States Government, International Journal of Engineering Science Invention, 4 (2), 53-69.

CUMHURBAŞKANLIĞI STRATEJİ VE BÜTÇE BAŞKANLIĞI, (2018), Kamu Özel İşbirliği ile Yürütülen Projeler, Ankara: Cumhurbaşkanlığı Strateji ve Bütçe Başkanlığg. https://koi.sbb.gov.tr [Erişim Tarihi: 24.11.2018].

ÇERÇİ, A., (2011), Kamu Özel İşbirlikleri (Public Private Partnerships-PPP) Modeller, Riskler ve Finansman, Ankara: Türkiye Kalkınma Bankası A.Ş., Ocak- Mart, Sayı: 59, 10-28.

ÇINAR, N. F., TÜRKOĞLU, Ç. ve TÜTÜNSATAR, A., (2017), Kamu-Özel Ortaklığı/Isşbirliği Modeli ve Sağlık Hizmetlerinin Sunumunda Hizmet Memnuniyetinin Ölçülmesi: Entegre Sağlık Kampüsleri (Şehir Hastaneleri) için Bir Araştırma, Süleyman Demirel Üniversitesi Sosyal Bilimler Enstitüsü Dergisi, Y11: 2017/4, Say1:29, 215-232.

DINAMO, (2018, 11 Kasım), Sağlık Sektöründe Kamu Özel Ortaklığı (PPP) Yöntemi ile Yatırımlara Genel Bakış, http://dinamo.co/wp-content/uploads/2017/02/saglik_sektoru .pdf [Erişim Tarihi: 20.01.2019].

GIVEN, L. M., (2008), The SAGE Encyclopedia of Qualitative Research Methods, The United States of America: SAGE Publication.

HARTWICH, F., TOLA, J., ENGLER, A., GONZÁlEZ, C., GHEZAN, G., VÁZQUEZALVARADO, J. M. P., SILVA, J. A., ESPINOZA, J. D. J. and GOTTRET, M. V., (2007), Building Public-Private Partnerships for Agricultural Innovation. Food Security in Practice Technical Guide Series, Washington, D.C.: International Food Policy Research Institute. 
INTERNATIONAL BANK FOR RECONSTRUCTION AND DEVELOPMENT (IBRD), (2014), Establishing the PPP Framework, Module 2, Public-Private Partnerships Reference Guide Version 2.0., Washington.

KAHYAOĞULLARI, B., (2013). Public-Private Partnerships in Developing and Developed Countries: The UK and Turkish Cases, Afyon Kocatepe Üniversitesi İiBF Dergisi, XV (II), 243-276.

KALKINMA BAKANLIĞI, (2014), Onuncu Kalkınma Planı (2014-2018) Kamu Özel İşbirliği Özel İhtisas Komisyonu Raporu, Ankara: Kalkınma Bakanlığı.

KALKINMA BAKANLIĞI, (2018), On Birinci Kalkınma Planı (2019-2023) Kamu Özel İşbirliği Özel İhtisas Komisyonu Ön Raporu, Ankara: Kalkınma Bakanlığı.

KARAHANOĞULLARI, Y., (2012), Kamu Özel Ortaklığı Modelinin Mali Değerlendirmesi, Ankara Üniversitesi SBF Dergisi, 67 (2), 95-125.

KESIK, A. ve TELLİ, Ç., (2014), Mali Alanı Yeniden Düşünmek: Kamu Özel İşbirliği Programları Türkiye için İmkanlar ve Kısıtlar, Mali Alan (Ed. Ahmet Kesik, Turgay Berksoy. Mehmet Şahin), 75-90.

MOSTEPANIUK, A., (2016), The Development of the Public- Private Partnership Concept in Economic Theory, Advances in Applied Sociology, 6, 375-388.

MOSZORO, M., (2010), Efficent Public-Private Partnership, Working Paper-884, Madrid: IESE Business School.

NEDERHAND, J. and KLIJN, E. H., (2017), Stakeholder Involvement in Public-Private Partnerships: Its Influence on the Innovative Character of Projects and on Project Performance, Administration anc Society, 1-27.

SUNDARAM, J. K., CHOWDHURY, A., SHARMA, K. and PLATZ, D., (2016), PublicPrivate Partnerships and the 2030 Agenda for Sustainable Development: Fit for Purpose?, DESA Working Paper, No: 148.

ŞAHIN, M., (2014), Altyapı Yatırımları için Mali Alan Mali Alan Oluşturmada Kamu Özel Sektör Ortaklıkları, Mali Alan (Ed. Ahmet Kesik, Turgay Berksoy. Mehmet Şahin), 169-185.

ŞAHIN, M. ve UYSAL, Ö., (2012), Kamu Maliyesine Etkileri Açısından Kamu Özel Sektör Ortaklıkları Üzerine Bir Değerlendirme, Maliye Dergisi, Sayı: 162, Ocak-Haziran, 155174.

T.C. GENÇLİK VE SPOR BAKANLIĞI, (2015), Yüksek Öğretim Kredi ve Yurtlar Kurumu Genel Müdürlüğü, Ön Protokol (15 Yıla Kadar Bina Kiralanması Genel ve Teknik Şartları, Değerlendirme Kriterleri, Ön Protokol ve Kira Sözleşmesi), Ankara.

TALUS, K., (2009), Enerjide Kamu - Özel Sektör Ortaklığı - Avrupa'da Kamu Hizmeti İmtiyazlarının ve İdari İşlemlerin Sonlandırılması, TBB Dergisi, Sayı: 84, 347-374.

TASAV, (2017), Kamu-Özel İşbirliği Projeleri: Türkiye ve Diğer Ülke Örnekleri, TASAV Ekonomi Araştırmaları Merkezi, TASAV: Türk Akademisi Siyasi Sosyal Stratejik Araştırmalar Vakfi.

TAYLOR, S. J., BOGDAN, R. and DEVAULT, M. L., (2016), Introduction to Qualitative Research Methods A Guidebook and Resource, Fourth Edition. Canada: Wiley.

TEKIN, P. Ş., (2017), Küresel Kamu Özel Ortaklığı Uygulamaları ve Türkiye Sağlık Sektörü Açısından Bir Değerlendirme, Ankara Sağllk Hizmetleri Dergisi, 16 (2), 5-20. 
TRACY, S. J., (2013), Qualitative Research Methods, Collecting Evidence, Crafting Analysis, Communicating Impact. Wiley-Blackwell.

TUNÇ, G. ve ÖZSARAÇ, E., (2015), Türkiye'deki Kamu Özel İşbirliği Modelinin İyileştirilmesine ait Öneriler, 3. Türkiye Deprem Mühendisliği ve Sismoloji Konferansı, Dokuz Eylül Üniversitesi, 14-16 Ekim 2015, İzmir.

UYGUN, B., (2013), Yeni Bir İlişki Türü: Kamu Özel Ortaklığı, Hukuk Gündemi, 2013/2, 2426.

VERMA, S., (2010). Government Obligations in Public-Private Partnership Contracts, Journal of Public Procurement, 10 (4), 564-598.

YERELİ, A. B. ve KIZILTAN, M., (2011), Kamu-Özel İşbirliği Projeleri ve Kırgızistan Ekonomisi Açısından Önemi, Intenational Conference on Eurasian Economies, 12-14 Ekim 2011, Kirgizistan, 246-252.

YETGİN, F. Ü., (2011), Kıyı Yatırımları ve Kamu Özel Sektör İşbirliği Modeli, 7. Kıyı Mühendisliği Sempozyumu, Trabzon, 20-23 Kasım 2011, 495-505.

YUSUFOĞLU, A., (2017), Kamu Özel Ortaklığı Projelerinde Koşullu Yükümlülükler ve Mali Riskler: Avrasya Tüneli, Osmangazi ve Yavuz Sultan Selim Köprüleri Üzerine Bir Değerlendirme, Gazi Üniversitesi İktisadi ve İdari Bilimler Fakültesi Dergisi, Gazi Akademi Genç Sosyal Bilimciler Sempozyumu 2017 Özel Sayısı, 156-174.

YÜKSEK ÖĞRENIM KREDİ VE YURTLAR KURUMU KANUNU (351 Sayıl1), (1961), Resmi Gazete, Tarih: 22/8/1961, Say1: 10887. 
KENANOĞLU / Kamu Özel Sektör Ortaklığı ve Kredi Yurtlar Kurumu Uygulamast: Çanakkale İli Örneğ $i$ 